Available online at GSC Online Press Directory

GSC Biological and Pharmaceutical Sciences

e-ISSN: 2581-3250, CODEN (USA): GBPSC2

Journal homepage: https://www.gsconlinepress.com/journals/gscbps

(RESEARCH ARTICLE)

\title{
Phytochemical compositions and biochemical effect of Phyllanthus amarus in albino rat
}

\begin{abstract}
Umar Itopa Sherif 1, Yusuf Abubakar Awwal 2, Alawode Adenike Rahmatallah ${ }^{3}$, Obiekezie Cyril Ifeanyi 4 Okunlola Banke Mary ${ }^{5}$, Abdulrazaq Ola Moshood ${ }^{4}$, Ariyeloye Stephen Damaola ${ }^{6}$ and Lawal Bashir ${ }^{4, *}$
\end{abstract}

${ }^{1}$ Department of Science and Laboratory Technology, Federal Polytechnic, Ile-Oluji, Nigeria.

2 Department of Biochemistry, Ibrahim Badamasi University Lapai, Nigeria.

${ }^{3}$ Forestry research institute of Nigeria-Southern Guinea Research Station, Mokwa, Niger State, Nigeria.

${ }^{4}$ Department of Biochemistry, Federal University of Technology Minna, P.M.B. 65, Nigeria.

${ }^{5}$ Department of Microbiology, Federal University of Technology Minna, P.M.B. 65, Nigeria.

${ }^{6}$ Department of Biochemistry, Federal University of Technology Akure-Ondo State, Nigeria.

Publication history: Received on 07 July 2019; revised on 21 July 2019; accepted on 25 July 2019

Article DOI: https://doi.org/10.30574/gscbps.2019.8.1.0125

\begin{abstract}
Phyllanthus amarus is a commonly known weed used for the traditional treatment of several aliment. In the present study, phytochemical screening and toxicological profile of methanol and aqueous extracts of $P$. amarus were investigated. Qualitative and quantitative phytochemical analysis were carried out using standard procedures. Subacute toxicity was carried out by oral administration of the aqueous extract at 300 and $600 \mathrm{ml} / \mathrm{kg}$ for $14 \mathrm{days}$. Biochemical parameters including aspartate amino tranferases (AST), alanine amino transfereas, (ALT), alkaline phosphates (ALP) albumin, total protein and albumin were investigated. The results obtained showed the presence of alkaloids, phenols, tannin, flavonoids, saponins, glycosides and steroids in both extracts. Quantitatively, alkaloids $(0.56 \pm 0.01$ and $0.56 \pm 0.00 \mathrm{mg} / \mathrm{g})$ were the most abundant phytochemical while phenol $(0.09 \pm 0.01 \mathrm{and} 0.07 \pm 0.01 \mathrm{mg} / \mathrm{g})$ was the least abundant in both extracts. The concentrations of total proteins were significantly $(\mathrm{p}<0.05)$ lowered in rats dosed with $600 \mathrm{mg} / \mathrm{kg}$ bw of the extract when compared with the control rats. However, serum activities of ALT, AST, ALP and albumins were not significantly $(\mathrm{p}>0.05)$ altered when compared with the control values. Methanol and aqueous extracts of $P$. amarus contains important phytochemicals with therapeutic reputations. The extract was also found not to have adverse/toxic effect on liver integrity at doses of up-to $600 \mathrm{mg} / \mathrm{kg} \mathrm{bw}$ in rats.
\end{abstract}

Keywords: Biochemical; Acute and sub-acute toxicity; P. amarus; Phytochemicals

\section{Introduction}

Natural products are important sources of bioactive metabolite with varied structural and therapeutic effect [1]. Decade of research has witnessed surfeit of research on therapeutic and medicinal properties of natural product owing to unsatisfactory and toxicity of synthetic drugs [1-3].

Phyllanthus amarus is a flowering plant of family Phyllanthaceae. It is highly distributed in most tropical and subtropical countries. It is commonly known as yin-olobe, geron tsuntsaye, susuma suyengi and Ngwu ite kwowa nasu by the Yorubas (South-Western), Hausas (Northern part), Nupes and the Igbos of the South-East of Nigeria respectively [4]. Previous phytochemical study of $P$. amarus confirmed the presence of bioactive metabolites including phyllantine, hypophyllantine alkaloids and flavonoids like quercetin, with diverse therapeutic values [5]. It is

\footnotetext{
${ }^{*}$ Corresponding author

E-mail address: Bashirlawal12@gmail.com
} 
commonly used in folk medicine for treatment of several diseases including hepatitis, malaria, fever, diabetes, stomach upset, cold anaemia, eczema, jaundice and as a remedy for blood disorders [6].

Extract of P. amarus exhibited antiplasmodial [7], cytotoxic activities [8], antidiarrheal [9], antioxidants [10] and hypolipidemic [5], effect. It is however, recommended that in addition to therapeutic values of plants, safety profile should be a major overriding criteria for the selection and uses of plant for health care need. It is in the view of this, that the present study was design to evaluate the phytochemical constituents as well as biochemical effect on liver integrity in rats.

\section{Material and methods}

\subsection{Collection and identification of plant materials}

Fresh leaves of Phyllanthus amarus were collected around the Federal University of Technology Minna Bosso campus on 24 $4^{\text {th }}$ March, 2017 and authenticated by a Botanist at Biological Science Department, Federal University of Technology Minna. The leaves were washed under running water, air dried and pulverized to obtain powdered form that was used for study. Chemicals and Reagents used were of analytical grade

\subsection{Experimental animal}

Total of twenty-five (25) Wister albino rats average weight $150.56 \pm 5.70 \mathrm{~g}$ were obtained from Animal house of School of life sciences, Federal University of Technology Minna. The rats were kept in the Laboratory under favuorable atmospheric conditions $\left(37^{\circ} \mathrm{C}\right)$ and acclimatized for two weeks before being used for the experiment. They were allowed accessed to commercial grower feed (Vital feed) and water ad-libitium.

The principles governing the use of laboratory animals as laid out by the Federal University of Technology, Minna Committee on Ethics for Medical and Scientific Research and also existing internationally accepted principles for laboratory animal use and care as contained in the Canadian Council on Animal Care Guidelines and Protocol Review were duly observed.

\subsection{Preparation of aqueous and methanol extracts}

Air-dried sample of P. amarus (150 g each) was extracted separately with $500 \mathrm{ml}$ of methanol using Soxhlet apparatus for 3 hours. Methanol extracts obtained was decanted and evaporated in rotatory evaporator at $65{ }^{\circ} \mathrm{C}$ respectively under a reduced pressure. Distilled water was used for the aqueous extraction using cold maceration. The aqueous extract was then filtered and evaporated using water bath. The concentrated extract obtained was preserved in sterile glass container and kept in refrigerator until the required time for use.

\subsection{Qualitative and quantitative phytochemical analysis}

Phytochemical analysis of extracts were carried out for the presence of alkaloids, flavonoids, tannins, saponins, glycosides, phenols and phlobatannins in methanol and aqueous extracts of $P$. amarus according to methods of [11]. Quantitative analysis was conducted for flavonoid, alkaloids, total phenol, tannin and saponins using standard procedures [12]

\subsection{Acute toxicity study}

Acute oral toxicity study was performed according to OECD -423 guidelines [13]. A total of fifteen (15) overnight fasted albino rats were randomly grouped in to three (5 each). Each extract was orally administered once at dose of 2500 $\mathrm{mg} / \mathrm{kg}$ body weight. Control group was given $0.2 \mathrm{ml}$ normal saline. The rats were observed every 30 minutes for 4 hours for detailed behavioral, neurological profile, delayed toxicity or mortality every day for 14 days.

\subsection{Sub-chronic Toxicity}

A total of twenty (20) rats were randomly divided into four groups of 5 rats each as follows: Each group was separately housed.

- Group A - Control groups that received no treatment.

- Group B - were administered $150 \mathrm{mg} / \mathrm{kg}$ aqueous extract of P. amarus

- $\quad$ Group C - were administered $300 \mathrm{mg} / \mathrm{kg}$ aqueous extract of P. amarus

- Group D - were administered $600 \mathrm{mg} / \mathrm{kg}$ aqueous extract of P. amarus 
All treatments were administered orally once daily for 14 days, after the $14^{\text {th }}$ days of the treatment with extract, the rat were then sacrificed.

\subsection{Collection of blood sample and analysis of biochemical parameters}

Collection of sample for biochemical analyses was as described previously [14]. The animals were anaesthetized with ether and blood was collected through cardiac puncture into a clean, dry EDTA- free centrifuge tubes. The blood samples were allowed to stand for 10 minutes at room temperature and then centrifuged at $1000 \mathrm{rpm}$ (503 x g) for 15 minutes to get the serum. Serum biochemical parameters including aspartate aminotransferase (AST), Alanine Aminotransferase (ALT), alkaline phosphatase, total proteins and albumin concentration were assay using standard procedures [15-17].

\section{Results}

\subsection{Phytochemicals}

The aqueous and methanol leaf extract of $P$. amarus contains alkaloids, phenols, tannis, flavonoids saponins, glycosides and steroids. Terpenoids was absent in methanol while phlobatannins was absent in both extracts (Table 1). Quantitatively, alkaloids were the most abundant phytochemicals while phenol was the least abundant in both extracts. The aqueous and methanol leaf contains $0.33 \pm 0.01$ and $0.28 \pm 0.01 \mathrm{mg} / \mathrm{g}$ of flavonoids, $0.56 \pm 0.01$ and $0.56 \pm 0.00$ of Alkaloid; $0.41 \pm 0.04$ and $0.34 \pm 0.02$ of Saponin; $0.09 \pm 0.01$ and $0.07 \pm 0.01$ of phenol; $0.34 \pm 0.05$ and $0.26 \pm 0.03$ of tannins respectively (Table 2).

Table 1 Phytochemical composition of Phyllanthus amarus

\begin{tabular}{lll}
\hline Phytochemcial & Aqueous & Methanol \\
\hline Alkaloid & + & + \\
Glcoside & + & + \\
Steroids & + & + \\
Tannins & + & + \\
Saponins & + & + \\
Phlobatannins & - & - \\
Terpenoids & + & - \\
Phenol & + & + \\
Flavonoids & + & + \\
\hline \multicolumn{2}{c}{ Key $+=$ Detected - = Not Detected }
\end{tabular}

Table 2 Quantitative phytochemical composition of methanol and aqueous extract of P. amarus

\begin{tabular}{lll}
\hline Parameter & Methanol $(\mathrm{mg} / \mathrm{g})$ & Aqueous $(\mathrm{mg} / \mathrm{g})$ \\
\hline Flavonoid & $0.33 \pm 0.01^{\mathrm{b}}$ & $0.28 \pm 0.01^{\mathrm{b}}$ \\
Alkaloid & $0.56 \pm 0.01^{\mathrm{d}}$ & $0.56 \pm 0.00^{\mathrm{d}}$ \\
Saponin & $0.41 \pm 0.04^{\mathrm{c}}$ & $0.34 \pm 0.02^{\mathrm{c}}$ \\
Phenol & $0.09 \pm 0.01^{\mathrm{a}}$ & $0.07 \pm 0.01^{\mathrm{a}}$ \\
Tannin & $0.34 \pm 0.05^{\mathrm{b}}$ & $0.26 \pm 0.03 \mathrm{~b}$ \\
\hline
\end{tabular}

Mean \pm Standard Error of triplicate determination. Values with different superscripts along a column are significantly different $(\mathrm{P}<0.05)$

\subsection{Acute toxicity test (limit test)}

For both aqueous and methanol extract, the behavioral profile (alertness, restleesness, irritability, fearfulness), neurological such as (reactivity, touch response and pain response) and autonomic profile (defecation and urination) were all normal during the side cage observation and beyond. Although they were less active for the first six hours but their activities became normal afterward. No mortality was recorded during the fourteen days of observation (Table 3). 
Umar et al. / GSC Biological and Pharmaceutical Sciences 2019, 08(01), 128-133

Table 3 Acute toxicity test of P. amarus (Limit Test)

\begin{tabular}{|c|c|c|c|c|}
\hline \multirow{2}{*}{$\begin{array}{l}\text { Group } \\
\text { dose }\end{array}$} & \multicolumn{4}{|c|}{ Extract activity } \\
\hline & Behavioral profile & Neurological profile & Autonomical profile & Mortality \\
\hline $\mathrm{A}$ & Normal & Normal & Normal & Nil \\
\hline B & Normal & Normal & Normal & Nil \\
\hline $\mathrm{C}$ & Normal & Normal & Normal & Nil \\
\hline
\end{tabular}

\subsection{Biochemical parameters}

The concentrations of total proteins were significantly $(\mathrm{p}<0.05)$ lowered in rats dosed with $600 \mathrm{mg} / \mathrm{kg}$ bw of the extract when compared with the control rats. However, serum concentrations of ALT, AST, ALP, total proteins and albumins were not significantly ( $\mathrm{p}>0.05$ ) altered when compared with the control values (Table 4).

Table 4 Effects of aqueous extract of $P$. amarus on biochemical parameters in albino rat

\begin{tabular}{llllll}
\hline Groups & AST (U/L) & ALT (U/L) & ALP (U/L) & TP (mg/dL) & Albumin (mg/dL) \\
\hline $150 \mathrm{mg} / \mathrm{kg}$ P. amarus & $48.84 \pm 4.34^{\mathrm{a}}$ & $70.89 \pm 4.32^{\mathrm{a}}$ & $231.78 \pm 7.64^{\mathrm{a}}$ & $70.43 \pm 3.84^{\mathrm{b}}$ & $4.76 \pm 0.29^{\mathrm{a}}$ \\
$300 \mathrm{mg} / \mathrm{kg}$ P. amarus & $56.34 \pm 4.24^{\mathrm{a}}$ & $72.22 \pm 6.34^{\mathrm{a}}$ & $220.56 \pm 13.01^{\mathrm{a}}$ & $72.97 \pm 4.99^{\mathrm{b}}$ & $4.98 \pm 0.06^{\mathrm{a}}$ \\
$600 \mathrm{mg} / \mathrm{kg}$ P. amarus & $49.90 \pm 5.77^{\mathrm{a}}$ & $73.01 \pm 8.02^{\mathrm{a}}$ & $233.24 \pm 11.87^{\mathrm{a}}$ & $56.31 \pm 7.94^{\mathrm{a}}$ & $4.86 \pm 0.53^{\mathrm{a}}$ \\
CONTROL & $49.97 \pm 5.05^{\mathrm{a}}$ & $70.01 \pm 6.24^{\mathrm{a}}$ & $236.03 \pm 15.67^{\mathrm{a}}$ & $72.48 \pm 1.11^{\mathrm{b}}$ & $4.76 \pm 0.36^{\mathrm{a}}$
\end{tabular}

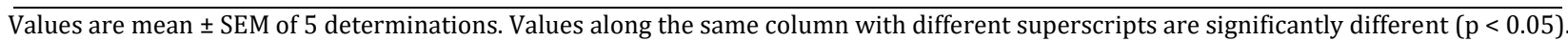

\section{Discussion}

The present study revealed the presence of various important medicinal phytochemicals in aqueous and methanol leaves extract leaf extract of $P$. amarus. The presence of flavonoid, tannin, saponin, steroid has been previously reported for methanol extract [6], and aqueous extract [11] of $P$. amarus. The phytochemicals identified in this study particularly, flavonoids, phenols and alkaloids (which is the most abundant phytochemicals in both extract $0.56 \pm 0.01$ and $0.56 \pm 0.00$ $\mathrm{mg} / \mathrm{g}$ ) are well known for diverse pharmacological activities [18]. Therefore, the present of these phytochemicals in aqueous and methanol leaf extract of P. amarus is an indication that this plant if properly screened could yield a drug of pharmaceutical significance. The higher amount of phytochemicals in methanol extract compared to that of aqueous extract indicated the bioactive agent in P. amarus are more soluble in polar organic solvent, this may confer higher biological activities to the methanol extract. However, the absence of terpenoids in methanol extract and the absence of Phlobatannins in both samples agree with early studies which also found that not all phytochemicals are present in all plant and those that present differs according to the solvent use in the extraction process [19]

In attempt to evaluate the safety or toxicity of plant extract, evaluation of biomarkers of organs integrity become relevant as it provides adequate diagnostic, prognostic information as well as pathological condition of animals exposed to the text substance [20]. In the present study, there was no test substance related mortality observed at limit dose of $2500 \mathrm{mg} / \mathrm{kg}$. Therefore, $P$. amarus could be generally regarded as safe (GRAS). This finding is in agreement with Clarke and Clarke [21], who reported that any compound or drug with oral LD50 estimates greater than $1000 \mathrm{mg} / \mathrm{kg}$ body weight could be considered to be of low toxicity and safe.

Alkaline phosphatases are often used to assess the integrity of plasma membrane and endoplasmic reticulum [22]. The observed non-significant difference from the control values in the activities of alkaline phosphatase (ALP) after 2 weeks of administrations of aqueous extract of $P$. amarus suggested that the integrity and functionality of endoplasmic reticulum and plasma membrane has not been comprised [23]. It also indicates that the extract did not inhibit or activate the activities of the enzyme molecule in situ [24]. AST and ALT are biomarkers of hepatic integrity and to a certain level can be used to assess the extent of hepatocellular damage, the ALT activities however, give more valuable information relevant to the integrity of the hepatocyte than AST [15]. The insignificant ( $p>0.05$ ) difference in the activities of AST and ALT in rats following administration of aqueous extract of $P$. amarus suggests that there were no leakages of these 
enzymes from liver into the serum. This indicated that hepatic metabolism of the P. amarus extract and tissue turnover, is not adversely affected [25].

The level of total protein plays important roles in determining the synthetic and excretory roles of the kidney and liver [15]. The results obtained in this study indicated that albumins and total proteins were not adversely effected by the extract administration at doses of 150 and $300 \mathrm{mg} / \mathrm{kg} \mathrm{bw}$. The observed decrease in the total proteins content in rats dosed with aqueous extract of $P$. amarus $(600 \mathrm{mg} / \mathrm{kg})$ for 2 weeks suggests that the extract might have interfered with the equilibrium in the rate of synthesis or destruction of total protein from the system of the animals [26]. Such decrease could, however, lead to hydration which is detrimental to cellular homeostasis. This will negatively affect the metabolic activities of the liver and consequently the health of the animals [21].

\section{Conclusion}

The findings of the present study indicate that methanol and aqueous extracts of P. amarus contains important phytochemicals of therapeutic application. The extract was also found not to have adverse/toxic effect on liver integrity at doses of up-to $600 \mathrm{mg} / \mathrm{kg}$ bw as revealed by biomarker enzyme, thus its safe for consumption.

\section{Compliance with ethical standards}

\section{Acknowledgments}

The authors would like to appreciate the technical staff, Department of Biochemistry, Federal University of Technology Minna for their kind assistance.

\section{Disclosure of conflict of interest}

The authors declare that they have no competing interests.

\section{Statement of ethical approval}

The principles governing the use of laboratory animals as laid out by the Federal University of Technology, Minna Committee on Ethics for Medical and Scientific Research and also existing internationally accepted principles for laboratory animal use and care as contained in the Canadian Council on Animal Care Guidelines and Protocol Review were duly observed.

\section{References}

[1] Ibrahim D, Hong LS and Kuppan N. (2013). Antimicrobial activity of crude methanolic extract from Phyllanthus niruri. Natural Product Communications, 8 (4), 493-496.

[2] Lawal B, Shittu OK, Inje OF, Berinyuy, EB and Muhammed H. (2016). African natural product with potential antioxidants and hepatoprotectives properties: A Review, Clinical Phytoscience, 2(23), 1-66.

[3] Bashir, L, Shittu, OK, Sani S, Busari MB, and Adeniyi KA. (2015). African natural products with potential antitrypanosoma properties: A review. Inter J Bioch Res Rev., 7(2), 45-79.

[4] Lawal B, Shittu OK, Kabiru AY, Jigam AA, Umar MB, Berinyuy EB and Alozieuwa BU. (2015). Potential antimalarials from African natural products: A review. J. Intercult Ethnopharmacol, 4(4), 318-343.

[5] Adeneye AA, Amole 00 and Adeneye AK. (2006). The hypoglycemic and hypocholesterolemic activities of the aqueous leaf and seed extracts of Phyllanthus amarus in mice. Fitoterapia, 77, 511-514.

[6] Obianime AW and Uche FI. (2009). The phytochemical constituents and the effects of methanol extracts of Phyllanthus amarus leaves (kidney stone plant) on the hormonal parameters of male guinea pigs. Appl. Sci. Environ. Manage, 13(1), 5- 9.

[7] Ramesh N, Yiswanathan MB, Saraswathy A, Balakrishna K, Brndha P and Lakshmanaperumalsamy P. (2010). Phytochemical and antibacterial studies of Bridelia crenulata. Pharmceutical Biology, 39(6), 460-464.

[8] Ajala TO, Igwilo CI, Oreagba IA and Odeku OA. (2011). The antiplasmodial effect of the extracts and formulated capsules of P. amarus on Plasmodium yoelii infectionin mice. Asian Pac J Trop Med 4, 283-287. 
[9] Lira DN, Uddin A, Uddin M and Rouf ASS. (2014). Assessment of cytotoxic activities of Phyllanthus amarus and Monstera deliciosa. Journal of Applied Pharmaceutical Science, 4(07), 110-113.

[10] Odetola AA and Akkojenu SM. (2000). Antidiarrhoeal and gastrointestinal potentials of the aqueous extracts of Phyllanthus amarus (Euphorbiaceae). Afri. J.Med. Sci, 29, 119-12.

[11] Karuna R, Sreenivasa S, Reddy R, Baskar D and Saralakumari B. (2009). Antioxidant potential of aqueous extract of Phyllanthus amarus in rats. Indian Journal of Pharmacology, 41 2, 64-67.

[12] Harborne JB. (1993). Phytochemical Methods; A guild to modern Techniques to plant anaylsis Freeman and Company. NY, 78-80.

[13] AOAC. (Association of official analytical chemist) (1990). Official Method analytical chemist, Washinton, D.C.

[14] OECD. [Organisation for Economic Co-operation and Development] (2000). Guidance Document on the Recognition Assessment and Use of Clinical Signs as Humane Endpoints for Experimental Animals Used in Safety Evaluation. Environmental Health and Safety Monograph Series on Testing and Assessment no. 19 Paris: OECD.

[15] Bashir L, Shittu OK, Busari MB, Sani S and Aisha MI. (2015). Safety evaluation of giant African land snails (Archachatina maginata) haemolymph on hematological and biochemical parameters of Albino rats. J Adv Med Pharm Science, 3(3), 122-30.

[16] Reitman S and Frankel S. (1957). A colorimetric method for the determination of serum glutamic oxalacetic and glutamic pyruvic transaminases. Am J Clin Pathology, 28, 56-63.

[17] Gornall AC, Bardawill CJ and David MM. (1949). Determination of serum protein by means of biuret reaction. J Biol Chemistry, 177, 751-66.

[18] Doumas BT, Watson WA and Biggs HG. (1971). Albumin standards and the measurement of serum album with bromocresol green. Clin Chem Acta, 31, 87-96.

[19] Jigam AA, Mahmood F and Lawal B. (2017). Protective effects of crude and alkaloidal extracts of Tamarindus indica against acute inflammation andnociception in rats Journal of Acute Disease, 6(2), 78-81.

[20] Lawal B, Ossai PC, Shittu OK and Abubakar AN. (2014). Evaluation of phytochemicals, proximate, minerals and anti-nutritional compositions of yam peel, maize chaff and bean coat. International Journal of Applied Biological Research, 6(2), 01-17.

[21] Lawal B, Shittu OK, Oibiokpa IF, Mohammed H, Umar SI and Haruna GM. (2016). Antimicrobial evaluation, acute and sub- acute toxicity studies of Allium sativum. Journal of Acute Disease, 5(4), 296-301.

[22] Clarke ML and Clarke EGC. (1967). Veterinary toxicology. London: Bailliere Tindall,

[23] Yusuf AA, Lawal B, Yusuf MA, Omonije YO, Adejoke AA, Raji FH and Wenawo DL. (2018). Free radical scavenging, antimicrobial activities and effect of sub-acute exposure to Nigerian Xylopia Aethiopica Seed extract on liver and kidney functional indices of Albino rats. Iranian Journal of Toxicology, 12(3), 51-58.

[24] Shittu OK, Lawal B, Alozieuwa BU, Haruna GM, Abubakar AN and Berinyuy EB. (2015). Alteration in biochemical indices follopapatawing chronic administration of methanolic extract of Nigeria bee propolis in Wister rats. Asian Pac J Trop Disease, 5(8), 654-7.

[25] Lawal B, Shittu OK, Abubakar AN, Umar MB, Ibrahim AM, Haruna GM. (2015). Biochemical evaluation in Wister rats (Rattus Novergicus) following chronic exposure of methanol leaf extract of Telfairia occcidentalis. J Pharm Biomed Science, 05(09), 740-744.

[26] Yusuf AA, Lawal B, Abubakar AN, Berinyuy EB, Omonije YO and Umar SI. (2018). In-vitro antioxidants, antimicrobial and toxicological evaluation of Nigerian Zingiber officinale. Clin Phytoscience, 4, 12.

[27] Shittu OK, Lawal B, Abubakar NA, Berinyuy BE, Busari MB and Ibrahim AO. (2015). Toxicological implications of methanol extract from Nigerian bee propolis on some selected rat tissues. J Pharm Biomed Science, 5(7), 524-31.

\section{How to cite this article}

Umar IS, Yusuf AA, Alawode AR, Obiekezie CI, Okunlola BM, Abdulrazaq OM, Ariyeloye SD and Lawal B. (2019). Phytochemical compositions and biochemical effect of Phyllanthus amarus in albino rat. GSC Biological and Pharmaceutical Sciences, 8(1), 128-133. 